\title{
SPEECH ACTS ADDRESSED AT HADZA INFANTS IN TANZANIA
}

\author{
MONIKA ABELS ${ }^{* 1}$ and PAUL A. VOGT ${ }^{1}$ \\ *Corresponding Author: monika.abels@gmail.com \\ ${ }^{1}$ Tilburg School of Humanities and Digital Sciences, Tilburg University, Netherlands
}

\section{Introduction}

Language socialization is known to differ between different human societies (e. g. Ochs \& Schieffelin, 1984). "Western" societies foster cognitive skills (e.g., language), but in many sub-Sahara African, rural societies (communal) action autonomy is considered more important (Keller, 2011). Different parental beliefs appear related to the speech acts addressed to children: Western, middle class caregivers tend to use more declaratives and questions when addressing their infants, whereas in many non-Western, rural communities caregivers tend to use relatively more imperatives (Rabain Jamin \& Sabeau-Jouannet, 1997; Vogt, Mastin, \& Schots, 2015).

Early language socialization has rarely been studied among hunter-gatherer communities. From an evolutionary point of view, studying the language socialization of hunter-gatherers could provide crucial insights into interactional settings that may have been similar for our ancestors (Marlowe, 2010). The egalitarian culture of hunter-gatherer societies (Marlowe, 2010) may influence the type of speech acts caregivers address to infants in unexpected ways. For example, it has been reported that hunter-gatherer infants receive few direct instructions, which could affect the amount of imperatives addressed to infants (Hewlett \& Roulette, 2016).

The Hadza are traditionally hunter-gatherers in northern Tanzania. Recent changes in livelihood can be observed in present day Hadza camps. For example more tourists visit some of the camps bringing money to pay for tour guides and souvenirs. These changes impact the Hadzas' lifestyle, and consequently may also influence the language socialization of their infants.

The following research questions are addressed in this study: (1) Are traditional child rearing ideals (i.e., little explicit instruction) reflected in caregivers' speech acts? (2) Do speech acts differ with camp livelihood? 


\section{Methods}

Twenty-five infants of $6-27$ months were visited in their camps with different livelihoods ((almost) daily contact with tourists $(n=7)$, occasional/indirect tourism or farming $(n=13)$, isolated $(n=5))$. After familiarization, infants were video-recorded on average 113 minutes (range 33-176) during their normal daily activities such as playing and eating. All videos were transcribed and translated to English by a native speaker of Hadzabe. Speech acts were coded as described by (Rabain-Jamin, 2001) as "Assertives", "Requests for Information" and "Requests for Action" and additionally "Vocatives" (Van de Weijer, 1999).

\section{Results and Discussion}

The results (cf. Appendix) suggest that Hadza infants experience speech acts similar to those of other infants in sub-Saharan Africa (Rabain-Jamin, 2001; Vogt et al., 2015), with very few assertives and requests for information, but frequent requests for actions. However, in isolated camps caregivers use significantly fewer requests for actions and relatively more vocatives than the less traditional camps. These findings suggest that traditional Hadza speech acts may have adhered to hunter-gatherer child rearing practices consisting of fewer imperatives than may be found in rural communities or less traditional huntergatherer communities, but considerably more than in Western communities. Furthermore, the low amount of assertives or requests for information indicates that the fostering of cognitive skills is not considered crucial, although this does not suggest that hunter-gatherers have no teaching strategies as is sometimes suggested (cf. Hewlett \& Roulette, 2016). It could also indicate that early human speech was not assertoric, as suggested by Tomasello (2010) but may have fulfilled function such as coordination and participation (Rappaport, 1999). The relatively high frequency of vocatives suggests an early fostering of relatedness (Biber et al., 1999), which may indicate a crucial role of communicating relations between people (Fitch, 2004) or assuring infants of caregivers' presence (Falk, 2004) during the early language evolution.

\section{Acknowledgements}

We thank all participating infants and caregivers. We are indebted to Ruth Matiyas, Mariamu Anyawire, Gudo Mahiya and Bernadetha Sanka for their help in data collection, transcription and translation. We are grateful to Andrew Kilale and John Ogondiek from the Tanzanian National Institute of Medical Research for their support. We thank Camilla Power from the University of East London for her help in planning and organizing this research and her input on Hadza culture. This project has received funding from the European Union through a Marie Skłodowska-Curie Actions Individual Fellowship (H2020MSCA-IF-2014) for the project "Hadza Communication". 


\section{References}

Biber, D., Johansson, S., Leech, G., Conrad, S., Finegan, E., \& Quirk, R. (1999). Longman grammar of spoken and written English (Vol. 2). Cambridge, MA: MIT Press.

Falk, D. (2004). Prelinguistic evolution in early hominins: whence motherese? Behav Brain Sci. 27 (4): 491-503.

Fitch, W. T. (2004). Kin selection and "mother tongues": a neglected component in language evolution. In U. Griebel \& D. K. Oller. Evolution of communication systems : a comparative approach. Cambridge, Mass.: MIT Press. pp. 275-296.

Hewlett, B. S., \& Roulette, C. J. (2016). Teaching in hunter-gatherer infancy. Royal Society Open Science, 3(1), 150403. http://doi.org/10.1098/rsos.150403

Keller, H. (2011). Autonomy and Relatedness Revisited: Cultural Manifestations of Universal Human Needs. Child Development Perspectives, 6(1), 12-18. http://doi.org/10.1111/j.17508606.2011.00208.x

Marlowe, F. (2010). The Hadza: Hunter-Gatherers of Tanzania (Origins of Human Behavior and Culture) (1st ed.). University of California Press.

Ochs, E., \& Schieffelin, B. (1984). Language acquisition and socialization: Three developmental stories and their implications. In R. Shweder \& R. Levine (Eds.), Culture theory: essays on mind, self and emotion (pp. 276320). New York: Cambridge University Press.

Rabain Jamin, J., \& Sabeau-Jouannet, E. (1997). Maternal speech to 4-monthold infants in two cultures: Wolof and French. International Journal of Behavioral Development, 20(3), 425-451. Retrieved from http://www.tandfonline.com/doi/abs/10.1080/016502597385216

Rabain-Jamin, J. (2001). Language use in mother-child and young sibling interactions in Senegal. First Language, 21(63), 357-385. http://doi.org/10.1177/014272370102106307

Rappaport, R. (1999). Ritual and religion in the making of humanity. Cambridge, U.K. New York: Cambridge University Press.

Tomasello, M. (2010) Origins of human communication. MIT press. Van de Weijer, J. C. (1999, January 11). Language Input for Word Discovery. (A. Cutler, Ed.). Katholieke Universiteit Nijmegen.

Vogt, P., Mastin, J. D., \& Schots, D. M. A. (2015). Communicative intentions of child-directed speech in three different learning environments:

Observations from the Netherlands, and rural and urban Mozambique. First Language, 35(4-5), 341-358.

http://doi.org/10.1146/annurev.an.15.100186.001115 
Appendix - statistics

Differences in speech acts by camp type

\begin{tabular}{|c|c|c|c|c|c|c|c|c|c|c|}
\hline \multirow[t]{2}{*}{ Speech act } & \multirow{2}{*}{$\begin{array}{l}F(2, \\
22)\end{array}$} & \multirow{2}{*}{$p$} & \multirow{2}{*}{$\begin{array}{l}\text { partial } \\
\eta^{2}\end{array}$} & \multicolumn{2}{|c|}{ Tourist } & \multicolumn{2}{|c|}{ Transitional } & \multicolumn{2}{|c|}{ Isolated } & \multirow{2}{*}{$\begin{array}{l}\text { LSD } \\
\text { Post- } \\
\text { hoc }\end{array}$} \\
\hline & & & & mean & SD & mean & SD & Mean & SD & \\
\hline \multicolumn{11}{|l|}{ Proportions } \\
\hline $\begin{array}{l}\text { Request for } \\
\text { information }\end{array}$ & 1.99 & .161 & .15 & 7.14 & 5.39 & 5.38 & 3.85 & 2.20 & 3.38 & - \\
\hline $\begin{array}{l}\text { Request for } \\
\text { action }\end{array}$ & 8.07 & .002 & .42 & 74.54 & 9.26 & 60.79 & 11.19 & 51.70 & 7.28 & $\begin{array}{l}\text { To }> \\
\mathrm{Tr}= \\
\text { Is }\end{array}$ \\
\hline Assertive & 4.00 & .033 & .27 & 11.59 & 8.25 & 21.05 & 7.50 & 15.41 & 4.89 & $\begin{array}{l}\operatorname{Tr}> \\
\text { To }\end{array}$ \\
\hline Vocative & 12.75 & $<.001$ & .54 & 6.73 & 5.88 & 12.78 & 8.40 & 30.69 & 10.88 & $\begin{array}{l}\text { Is }> \\
\operatorname{Tr}= \\
\text { To }\end{array}$ \\
\hline $\begin{array}{l}\text { Total } \\
\text { number of } \\
\text { speech } \\
\text { acts/minute }\end{array}$ & & & & 0.80 & 0.52 & 0.75 & 0.47 & 1.28 & 0.49 & \\
\hline
\end{tabular}

